\title{
Advanced Cycles Large-Scale Aero-Derivative Gas Turbines: Performance Comparison
}

\author{
Barinyima Nkoi ${ }^{*}$, Thank God Ebi Isaiah ${ }^{2}$ \\ ${ }^{1}$ Department of Mechanical Engineering, Rivers State University of Science and Technology, Port Harcourt, \\ Nigeria \\ ${ }^{2}$ Department of Mechanical Engineering, Niger Delta University, Wilberforce Island, Nigeria \\ Email: "nkoi.barinyima@ust.edu.ng,nkoinyima@yahoo.com,thankgod607@yahoo.com
}

Received 2 April 2016; accepted 9 May 2016; published 12 May 2016

Copyright (C) 2016 by authors and Scientific Research Publishing Inc.

This work is licensed under the Creative Commons Attribution International License (CC BY). http://creativecommons.org/licenses/by/4.0/

(c) () Open Access

\begin{abstract}
This paper aims at carrying out comparative performance analysis of simple and advanced cycles large-scale aero-derivative industrial gas turbines derived from aircraft turbofan engines. The investigation involves technical performances of three large-scale aero-derivative engine cycles based on existing and projected cycles for applications in land based power generation and Combined-Heat-and-Power (CHP). Preliminary design and performance simulation were implemented of a simple cycle (baseline) three-spool $100 \mathrm{MW}$ aero-derivative engine model, intercooled and intercooled/recuperated engine cycles of the same $100 \mathrm{MW}$ nominal power rating. In the analysis, design point and off-design performances of the engine models were established. The results indicate that to a large extent, the advanced engine cycles showed superior performance in terms of thermal efficiency, and fuel flow. In numerical terms, thermal efficiencies of intercooled engine cycle, and intercooled/recuperated engine cycles, over the simple cycle at design point increased by $2.42 \%$ and $0.94 \%$ respectively, whereas heat rates of these cycles over simple cycle at design point decreased by $2.37 \%$ and $0.93 \%$ respectively. It is worthy of note that for large-scale aeroderivative gas turbines having power rating of $100 \mathrm{MW}$ and above, intercooled cycle would consume less fuel than intercooled-recuperated and simple cycles. This finding would actually aid good choice of cycle option for large-scale aero-derivative gas turbine designers, manufacturers and users.
\end{abstract}

\section{Keywords}

Aero-Derivative-Gas-Turbines, Thermal-Efficiency, Intercooled-Recuperated, Fuel-Flow, Heat-Rate

\footnotetext{
*Corresponding author.
} 


\section{Introduction}

Aero-derivative industrial gas turbines (ADIGT) could be grouped into three categories namely: small-scale, medium-scale, and large-scale aero-derivatives, based on different ranges of power ratings. Small-scale ADIGT category can be defined as having the range of power rating from about $0.6 \mathrm{MW}$ up to $5 \mathrm{MW}$. The range of power rating greater than $5 \mathrm{MW}$ but up to $20 \mathrm{MW}$ could be classified as medium-scale category. Large-scale category would be considered as the class having power rating above $20 \mathrm{MW}$ [1]-[3]. As the name implies, aero-derivative industrial gas turbines (ADIGT) are gas turbines derived from aero-gas turbine engines by means of conversion. The decision to use aero-derivative gas turbines is mainly based on economical and operational advantages. Gas turbine manufacturers have found that to reduce cost of designing and developing new gas turbines, a more effective approach is to develop high performance industrial gas turbines by modifying aircraft gas turbine engines [4] [5]. Also, by introducing aero-derivative's removable gas generator, better flexibility is provided which in turn leads to reducing maintenance operation and enhancing gas turbine availability in industrial applications [6]. More so, implementing aero-derivative technology for industrial gas turbine has resulted in low maintenance downtime, good part-load efficiencies and higher rate of return [4]-[7].

It has been reported that the introduction of modern, high thrust aero-engines for aircraft propulsion has resulted in the development of a commensurate range of new high power, high efficiency ADIGT. This is illustrated for instance by the Rolls-Royce TRENT. The development of these large, efficient ADIGT offers particular chances for use in power generation and combined-heat-and-power plant [4]. ADIGT gives various advantages over their industrial design counterparts, in technology, project implementation and maintenance. Comparing performance, modern ADIGTs present a very efficient form of simple cycle energy conversion and this is exemplified in the TRENT GT. The high efficiency of the TRENT engine makes it a distinct choice for simple cycle application. With a state-of-the-art technology development from a modern aero-engine, fiscal studies have indicated that the high efficiency aero-derivative version exceedingly counterpoises for higher first cost that could be expected. Modern ADIGTs are also a feasible option for Combined-cycle-gas-turbine (CCGT) and CHP applications where power in the $60-120 \mathrm{MW}$ class is anticipated. The TRENT GT, having a combined-cycle efficiency of about $51.5 \%$, is one of the most competitive options available in its class. Modern ADIGT plants are an amply-embraced alternative for energy generation and this progression is expected to advance with the TRENT and future developments [3]-[8].

Besides, another instance is the GE LM6000 aero-derivative gas turbine series which has undergone some new innovations in technology especially those in the $35-65 \mathrm{MW}_{\mathrm{e}}$ range. The GE LM6000 has the latest innovations in the LM6000PG \& PH versions. These are denoted as the "PG" for the standard annular combustor (SAC) and "PH" for the dry low emissions (DLE) model. The improved technologies for these new products include new higher temperature alloys and improved cooling pattern to withstand high combustor outlet temperature, LP compressor operating at higher speed and increased mass flow, and higher pressure ratio. The GE LM6000 PG offers a 25\% simple cycle power increase compared to the GE LM 2500, its predecessor, owing to advanced technology [9]. The advancement to the GE LM6000 gas turbine produces an 18\% increase in the exhaust energy and $25 \%$ increase in power, and about $52 \%$ combined-cycle efficiency when incorporated into a 2on-1 reference combined-cycle plant [9].

More so, aero-derivative gas turbines can meet stringent NOx control requirements because they are suitable for power augmentation by steam injection. For instance, the GE LM series industrial aero-derivative gas turbines are meeting NOx requirements as low as 25 parts per million ( $\mathrm{ppm}$ ) using steam injection. Other merits of aero-derivative gas turbines include low weight-to-power ratio, compactness, and hence, lesser erection and startup time [10] [11]. More so, aero-derivative gas turbine are most suitable for highly efficient cogeneration plants, more flexible combined-cycle plants, and in mechanical drive applications for production and distribution of oil and gas [12].

Using heat exchangers (both recuperators and intercoolers) in an engine exhibits tremendous potential to cut fuel consumption and thereby reducing $\mathrm{CO}_{2}$ emissions. It was explained that the recuperator utilizes part of heat from the exhaust gas to raise the temperature of the air entering the combustor [13]. This method achieves the same turbine entry temperature as obtainable in conventional power plants but with the advantage of utilizing lesser fuel [13]. Besides, gas turbine user requirements have, over the years, necessitated technological advancement in engine performance, and comprehensive researches are being conducted to achieve this [14] [15].

Technically, improvement of thermal efficiency for industrial and aero gas turbines is of paramount importance to the overall performance of the engines. Increase in thermal efficiency depends on certain factors in- 
cluding: Changes in some engine cycle parameters, such as overall pressure ratio (OPR), and turbine entry temperature (TET). Cutting-edge technology of engine components like methods of cooling, efficiencies of components, ducts pressure losses, and introduction of different overall thermodynamic cycle, for example, use of unconventional components like intercoolers and regenerators or recuperators [5] [16]. More so, performance and economic viability of gas turbines are inseparable [15].

The aim of this paper is to compare the technical performances of large-scale aero-derivative industrial gas turbines. The investigation encompasses comparative assessment of simple (SC), intercooled (IC), and intercooled/recuperated (ICR) cycle options. This sort of analysis would surely aid good choice of engine cycle options in the category of large-scale aero-derivative land based gas turbines. GE Power has developed, manufactured and deployed 100 MW large-scale intercooled aero-derivative gas turbine in the LMS100 series [17], however, this research introduces analysis of a $100 \mathrm{MW}$ intercooled-recuperated aero-derivative gas turbine and a counterpart simple cycle version. Hence, this research has the advantage of providing wider range of cycle options in this category of aero-derivative gas turbines.

\section{Materials and Methods}

\subsection{Design Point Performance (DP)}

The Design Point of a gas turbine could be defined as the very condition in the operating range of a gas turbine when the engine is running at the very mass flow, speed, and pressure ratio for which the components were designed [18]. In establishing the design point of the engine, pressure ratio and TET that results in an overall highest thermal efficiency are normally determined from preliminary cycle calculations. After this is done, other appropriate design parameters of the gas turbine system may be allotted. Then, detail design of different engine components can be done in order to provide the specified requirements of the complete system when operating at the DP. There are many requirements from a gas turbine engine. These may be referred to as design priorities, and always these requirements are in conflict. The design of the engine is greatly influenced by a set of these priorities depending on the engine application [5] [15] [19] [20].

\subsection{Off-Design Performance (OD)}

Besides the DP performance of the gas turbine, it is mandatory to ascertain its general performance over the entire operating range of power output and speed. This is known as Off-Design (OD) performance [18]. Component characteristics as indicated by component maps of compressor, turbine, and combustor, are very useful in ascertaining off-design behaviour of the gas turbine system. At steady state operation of the engine, corresponding operating points on the component maps are matched and can be plotted on the compressor characteristic diagram to form an equilibrium running line [20].

Various performance plots of power output, specific fuel consumption (sfc), thrust, specific thrust or power, etc could be made once the operating conditions of an engine have been determined. It is important to note that off-design performance is very much affected by factors such as ambient conditions of temperature and pressure, altitudes, flight speed (for aero engines), etc. The off-design performance analysis is normally achieved by the use of computer model simulations of engines [20] [21].

\subsection{TURBOMATCH}

Engine components operating point matching to establish OD performance is normally a tedious and time consuming task since it is an iterative process. Computer based simulation is normally employed to accomplish the task. TURBOMATCH is an in-house gas turbine engine performance software developed and established at Cranfield University (CU). It is employed to simulate the DP and OD performances of a broad range of aero and industrial gas turbines. Simple single shaft engines, complex multi-spool engines, as well as novel cycle engine configurations can be modelled adequately using the scheme [15]-[16] [18]-[20].

In the scheme, different engine components (intake, compressor, combustor, turbine, nozzle, etc) are represented by bricks (building blocks of the programme). These bricks are pre-programmed routines deployed to simulate, on a modular basis, the performance of the various engine components they represent. The cycle thermal efficiency, specific fuel consumption, power, or thrust of the engine, etc. are essential performance output parameters that are obtained as desired results of the simulation. Besides these overall cycle results, individual 
component performance characteristics, and the working-fluid properties at various stations within the engine are also outputted [15] [18] [22] [23].

\subsection{Simple Cycle Three-Spool Turboshaft Engine with Free Power Turbine}

In this paper, three-spool turboshaft engine with a free power turbine (FPT) was considered in which a high pressure compressor (HPC) is driven by the high pressure turbine (HPT) and a low pressure compressor (LPC) is driven by an intermediary low pressure turbine (IPT). The schematic representation of such engine is shown in Figure 1 indicating station numbers.

The T-S diagram of the simple cycle is shown in Figure 2 considering isentropic efficiencies of compressors and turbines. With the notations of Figure 1 and Figure 2, and applying steady flow energy equation, heat flow into the cycle in the combustion chamber (process 4 - 5) per unit air mass flow is given by Equation (1).

$$
q_{\text {in }}=h_{5}-h_{4}=c_{p i}\left(T_{5}-T_{4}\right)
$$

where $c_{p i}$ is the specific heat capacity at constant pressure, which varies with temperature at the given engine component station $i . i$ represents engine station numbers 1, 2, 3, 4, 5, 6 etc.

Heat rejected at constant pressure (process 8 - 2) in the exhaust is given by Equation (2).

$$
q_{\text {out }}=h_{8}-h_{2}=c_{p i}\left(T_{8}-T_{2}\right)
$$

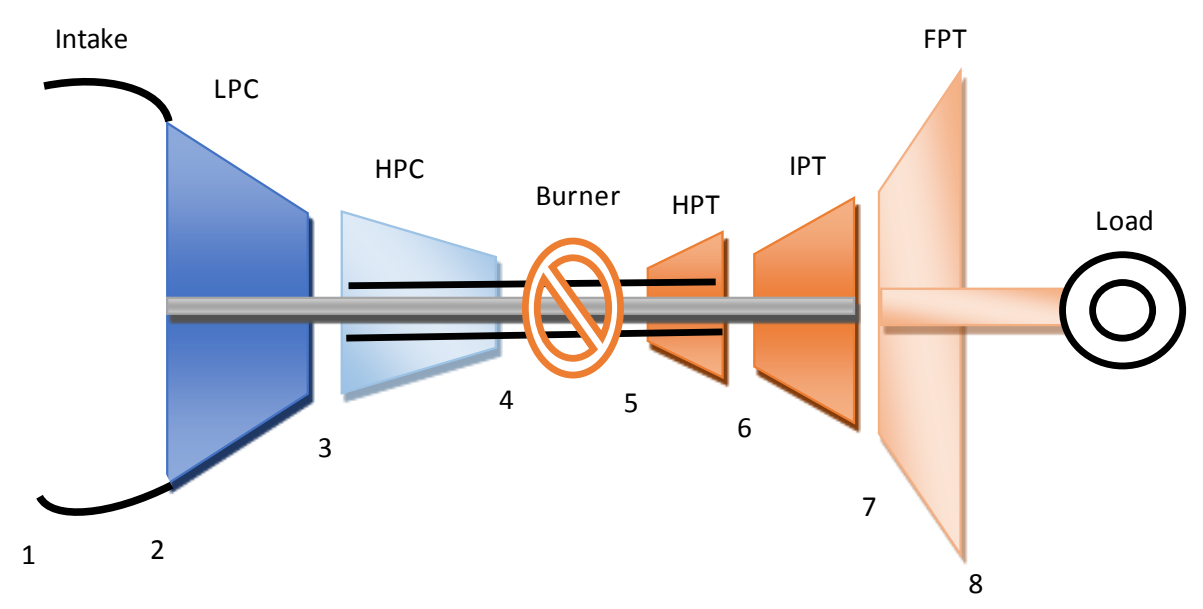

Figure 1. Schematics of a three-spool turboshaft engine with free power turbine.

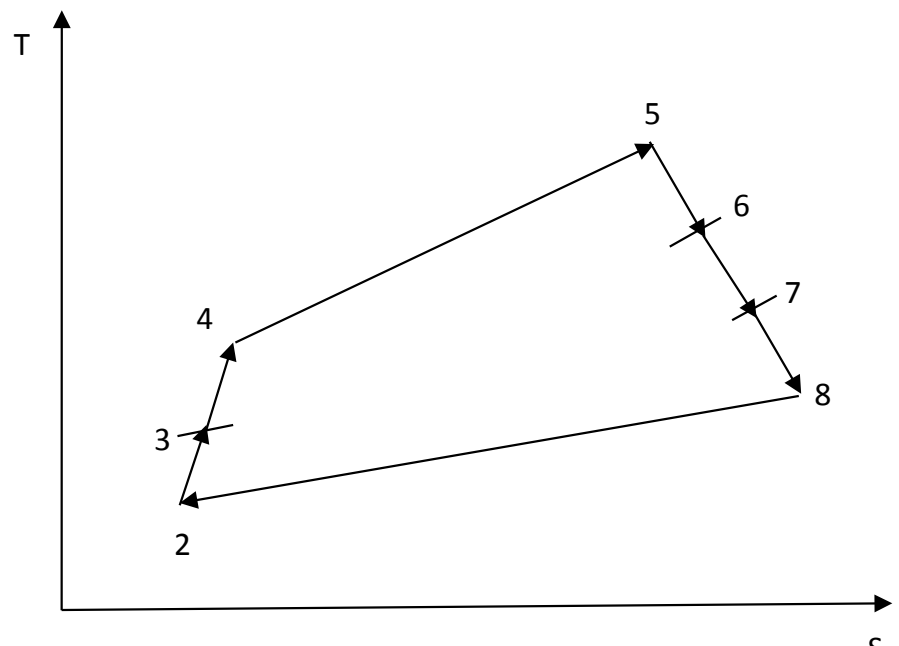


Equation (3) or Equation (4) gives the total compressor work (CW) (process 2-3-4) per unit air mass flow, where process $2-3$ occur in the LPC and process $3-4$ occur in the HPC.

$$
\begin{gathered}
C W=L P C W+H P C W=\left(h_{3}-h_{2}\right)+\left(h_{4}-h_{3}\right) \\
C W=c_{p i}\left[\left(T_{3}-T_{2}\right)+\left(T_{4}-T_{3}\right)\right]
\end{gathered}
$$

High pressure turbine work (HPTW) (process 5 - 6) per unit air mass flow is defined by Equation (5).

$$
H P T W=h_{5}-h_{6}=c_{p i}\left(T_{5}-T_{6}\right)
$$

Intermediary pressure turbine work (IPTW) (process 6 - 7) given by Equation (6)

$$
I P T W=h_{6}-h_{7}=c_{p i}\left(T_{6}-T_{7}\right)
$$

Free power turbine work (FPTW) (process 7 - 8) given by Equation (7)

$$
F P T W=h_{7}-h_{8}=c_{p i}\left(T_{7}-T_{8}\right)
$$

This implies that total expansion work (EW) is obtained as stated in Equation (8)

$$
\begin{gathered}
E W=H P T W+I P T W+F P T W \\
E W=c_{p i}\left[\left(T_{5}-T_{6}\right)+\left(T_{6}-T_{7}\right)+\left(T_{7}-T_{8}\right)\right]
\end{gathered}
$$

The thermal efficiency is calculated using Equation (9) below.

$$
\eta_{t h}=\frac{\text { useful work }}{\text { heat input }}=\frac{E W-C W}{c_{p i}\left(T_{5}-T_{4}\right)}
$$

\subsection{Modifications to the Simple Cycle}

To increase the efficiencies of the simple-cycle, unconventional components are added to the cycle. These components include intercoolers, regenerators (recuperators), or reheaters. However, the initial and maintenance costs of the cycle may increase due to these additional components. The improvements in cycle performance brought about by these components can only be justified if the decrease in fuel costs offsets the increase in other costs. There is the general urge to reduce fuel consumption in gas turbine operation [24]. This is achieved by the introduction of these modifications to the simple cycle. The descriptions of these modifications are outlined below [15].

\subsubsection{Intercooled Cycle}

Incorporating an intercooler between the LPC and HPC of the simple cycle engine in section 2.4 such that air leaving the LPC is cooled before entering the HPC, results in an intercooled cycle. Intercooling reduces the total compressor work, thereby, increasing useful work output, turbine work remaining the same [5]. Also, intercooling will increase the specific work of the cycle, increase heat input from combustor, and thus fuel consumption will rise [25]. The T-S diagram of the intercooled three-spool engine cycle is shown in Figure 3.

\subsubsection{Intercooled/Recuperated Cycle}

Incorporating a recuperator between the outlet of the HPC and outlet of the LPT of the intercooled engine in section 2.5.1 such that air leaving the HPC is heated before entering the burner, results in an intercooled/recuperated cycle. The recuperator or regenerator is a heat exchanger connected between the turbine exhaust and the compressor exit. The thermal efficiency of the cycle increases due to recuperation because the portion of heat in the exhaust gases that is supposedly wasted by flaring is now utilised to preheat the air at the exit to the compressor. This, in effect, reduces the heat gain from burning fuel, and hence, decreases fuel consumption for same power output. However, if the compressor outlet temperature is equal or higher than the turbine exhaust temperature, the use of a regenerator is not recommended. Else, there will be a reversal of heat flow to the exhaust gases, causing the efficiency to decrease. Very high pressure ratios in gas-turbine engines could cause this adverse 


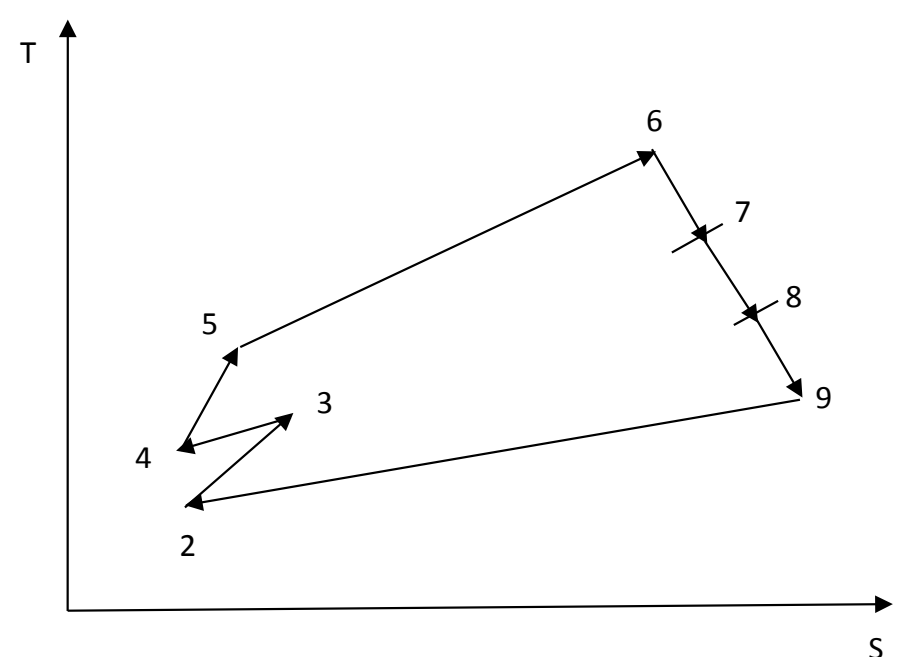

Figure 3. T-S diagram of actual intercooled cycle three-spool gas turbine.

situation [15]. However, the intercooler effect of reducing thermal efficiency is compensated by recuperation effect in ICR. The T-S diagram for the cycle with both intercooling and recuperation is shown in Figure 4, where process $9-10-11$ is recuperation (regeneration).

Referring to the cycle in Figure 4, $\mathrm{T}_{9}$ is the maximum temperature that can occur within the recuperator which is the temperature of the exhaust gases entering the recuperator and leaving the turbine. Air in the regenerator (recuperator) can only be preheated to a temperature below $T_{9}$, and air will normally exit the regenerator at $\mathrm{T}_{10}$, a lower temperature [15] [26].

Using the station numbering and notations in the T-S diagram of Figure 4.

The heat input per unit air mass flow here is given by Equation (10).

$$
q_{\text {in }}=h_{6}-h_{10}=c_{p i}\left(T_{6}-T_{10}\right)
$$

Here, compressor work is given by Equation (11), and Equation (12) gives the expansion work.

$$
\begin{gathered}
C W=L P C W+H P C W=\left(h_{3}-h_{2}\right)+\left(h_{5}-h_{4}\right) \\
C W=c_{p i}\left[\left(T_{3}-T_{2}\right)+\left(T_{5}-T_{4}\right)\right] \\
E W=c_{p i}\left[\left(T_{6}-T_{7}\right)+\left(T_{7}-T_{8}\right)+\left(T_{8}-T_{9}\right)\right]
\end{gathered}
$$

Equation (13) calculates the thermal efficiency in this case with reference to Equation (11) and Equation (12).

$$
\eta_{t h}=\frac{\text { useful work }}{\text { heat input }}=\frac{E W-C W}{c_{p i}\left(T_{6}-T_{10}\right)}
$$

TURBOMATCH code is capable of computing engine performance parameters using thermodynamic relations and models, considering variations of properties of working fluid at different conditions of pressure and temperature [21]-[23].

\section{Analysis and Results}

\subsection{Simple Cycle Three-Spool Aero-Derivative Gas Turbine (Base-Line Engine Core)}

For the engine model, a simple cycle three-spool engine inspired by the aero-derivative GE LMS100 core is chosen as the baseline engine. The LMS100 turbine has a free power turbine (FPT), an intermediary turbine (IPT) that drives the LPC, and an intercooler. With an overall compression ratio of $42: 1$, it has an annular combustor equipped with dry low emission (DLE) technology, and an air-cooled HPT which drives the HPC. The LMS100 was derived from the LM6000 by the addition of the intercooler and free power turbine delivering an 


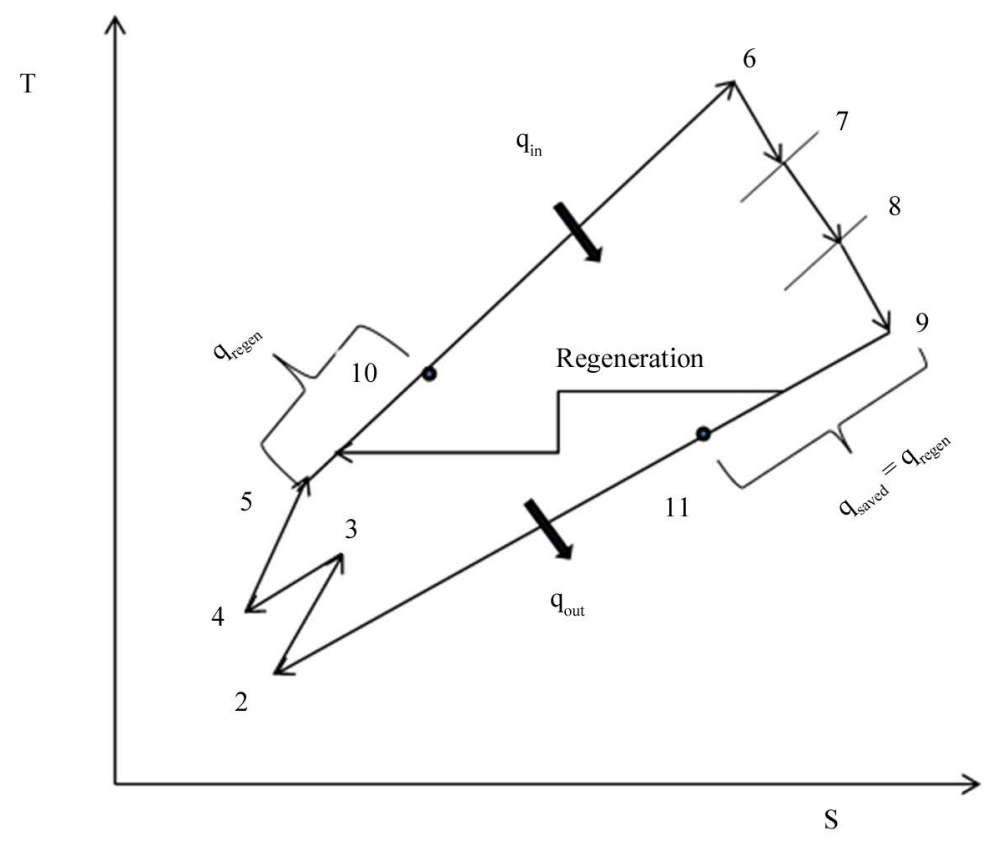

Figure 4. T-S Diagram of actual intercooled-recuperated 3-spool gas turbine cycle.

output power of about $100 \mathrm{MW}[17]$.

It should be understood that the design point of the inspiring engine core is proprietary information of the original equipment manufacturer (OEM), and as such, the design point is reasonably chosen by engineering judgment. This is because some key defining parameters of the DP like the turbine entry temperature (TET), etc. are not usually disclosed by the OEM [15] [27]. Based on this fact, and due to availability of data, international standard atmosphere (ISA)-sea level static (SLS) was chosen as the design point with the adoption of U.S.A.F. standard for pressure recovery at intake.

The engine components were modelled in TURBOMATCH bricks shown in Figure 5. The DP was chosen as ISA SLS condition of $100 \mathrm{MW}$ output power. The isentropic efficiencies of both the LPC and HPC were assumed to be 0.875 , with a surge margin of 0.80 . The design pressure ratios of the LPC and HPC are 3.0 and 14.05 respectively, giving an overall pressure ratio of about 42.15:1. The LPC is driven by LP spool of the IPT and the HPC is driven by the HP spool of the HPT. The turbine entry temperature was assumed to be $1730 \mathrm{~K}$ and taken as the engine handle for the simulation, while the air mass flow was set at $215.5 \mathrm{~kg} / \mathrm{s}$ with $8.0 \%$ mass bleed for cooling of the compressor turbines inlet blades. A combustion chamber pressure loss of $5 \%$ of the HPC delivery pressure was allowed whereas the combustor efficiency of 0.998 was assumed. The isentropic efficiency of the HPT and the IPT were taken to be 0.89 , and that of the free power turbine was set at 0.90 . Default nondimensional speed of 0.6 , and a non-dimensional mass flow of 0.8 , were used. The simulation results were generated, and summarized in Table 1 .

\subsection{Design Point Performance of Intercooled Three-Spool Large-Scale-ADIGT Engine}

The simple cycle LS-ADIGT engine described in section 3.1 is modified by introducing an intercooler between the LP and HP compressors. While retaining component efficiencies, TET, and inlet mass flow, the air leaving the LP compressor is cooled to a temperature of $320^{\circ} \mathrm{C}$, with intercooler effectiveness of $30 \%$, and intercooler pressure loss of $3 \%$ of LPC delivery pressure. However, a mass bleed totaling $27 \%$ of intake air mass flow is channeled for both HPT and IPT inlet blades cooling. The intercooled engine arrangement is shown in Figure 6 in TURBOMATCH bricks, and the DP performance results are summarized in Table 1.

\subsection{Design Point Performance of ICR Three-Spool LS2-ADIGT Engine}

The intercooled/recuperated three-spool large-scale aero-derivative engine components in TURBOMATCH bricks is shown in Figure 7. The core engine parameters of the intercooled LS-ADIGT described in section 3.2 
LPT blades cooling bleed

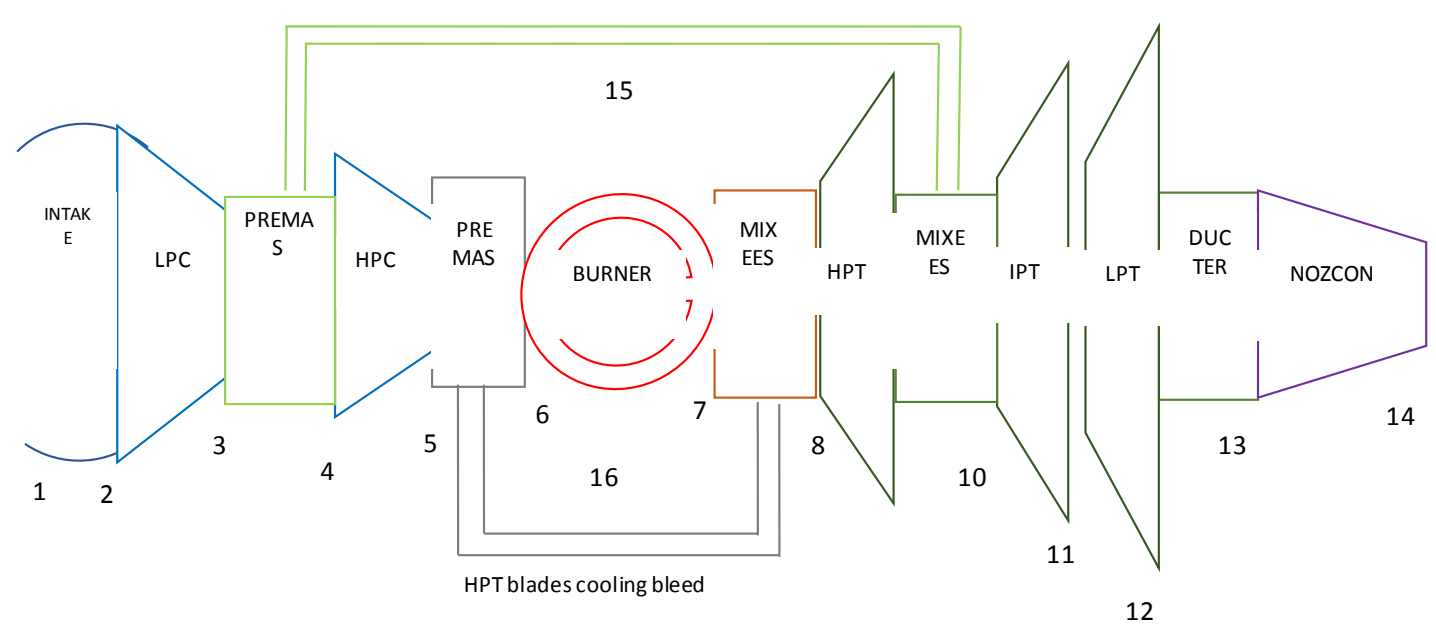

Figure 5. Simple cycle 3-spool Large-scale-ADIGT engine components in TURBOMATCH bricks (inspired by GE LMS100 core).

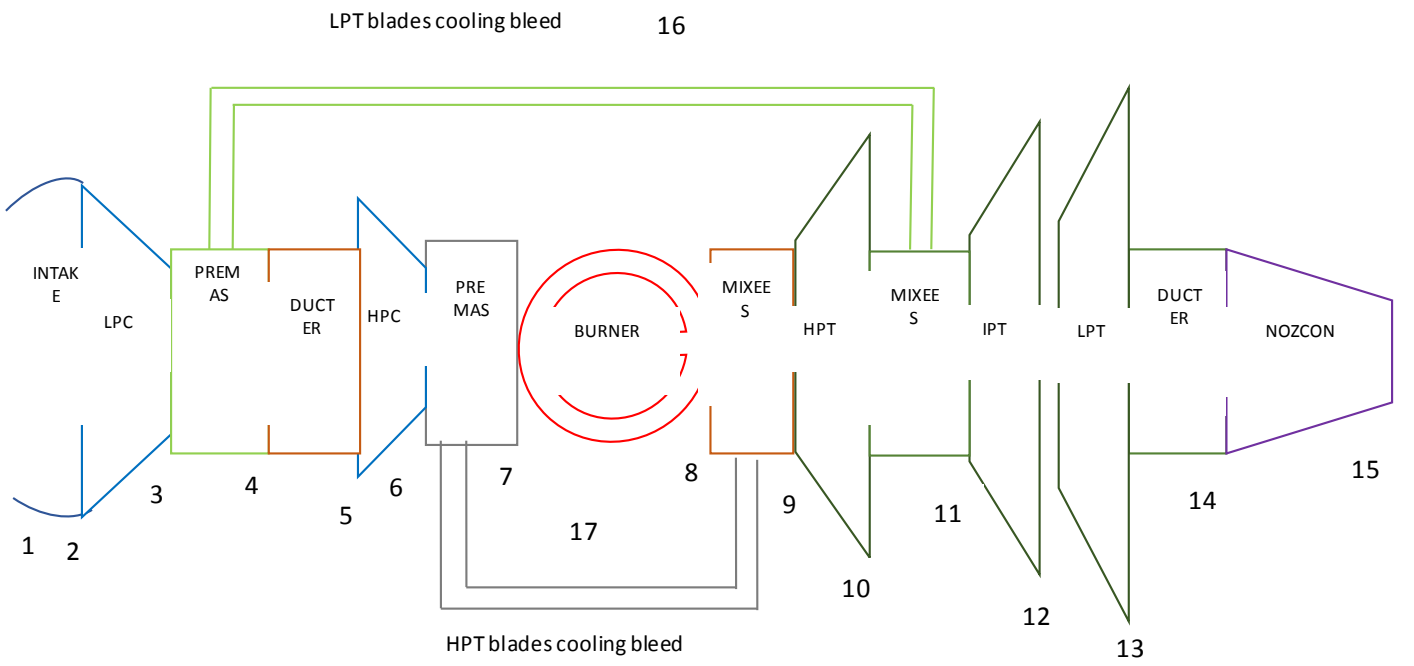

Figure 6. Intercooled 3-spool LS2-ADIGT engine components in TURBOMATCH bricks (inspired by GE LMS100 core).

Table 1. Summary of DP performance results of the LS2-ADIGT engines simulation.

\begin{tabular}{cccc}
\hline Performance parameter & \multicolumn{2}{c}{ Value at DP of simulated three-spool LS2-ADIGT engines } \\
\cline { 2 - 4 } Power turbine rating (kW) & Simple cycle & Intercooled & 100,000 \\
Inlet mass flow (kg/s) & 100,000 & 100,000 & 215.5 \\
Exhaust mass flow (kg/s) & 215.5 & 215.5 & 220.54 \\
Fuel flow (kg/s) & 220.59 & 220.47 & 5.04 \\
Exhaust gas temperature (K) & 5.09 & 4.97 & 690 \\
Overall compression pressure ratio & 783 & 692 & $42.15: 1$ \\
Thermal efficiency & $42.15: 1$ & $42.15: 1$ & 0.460 \\
\hline
\end{tabular}




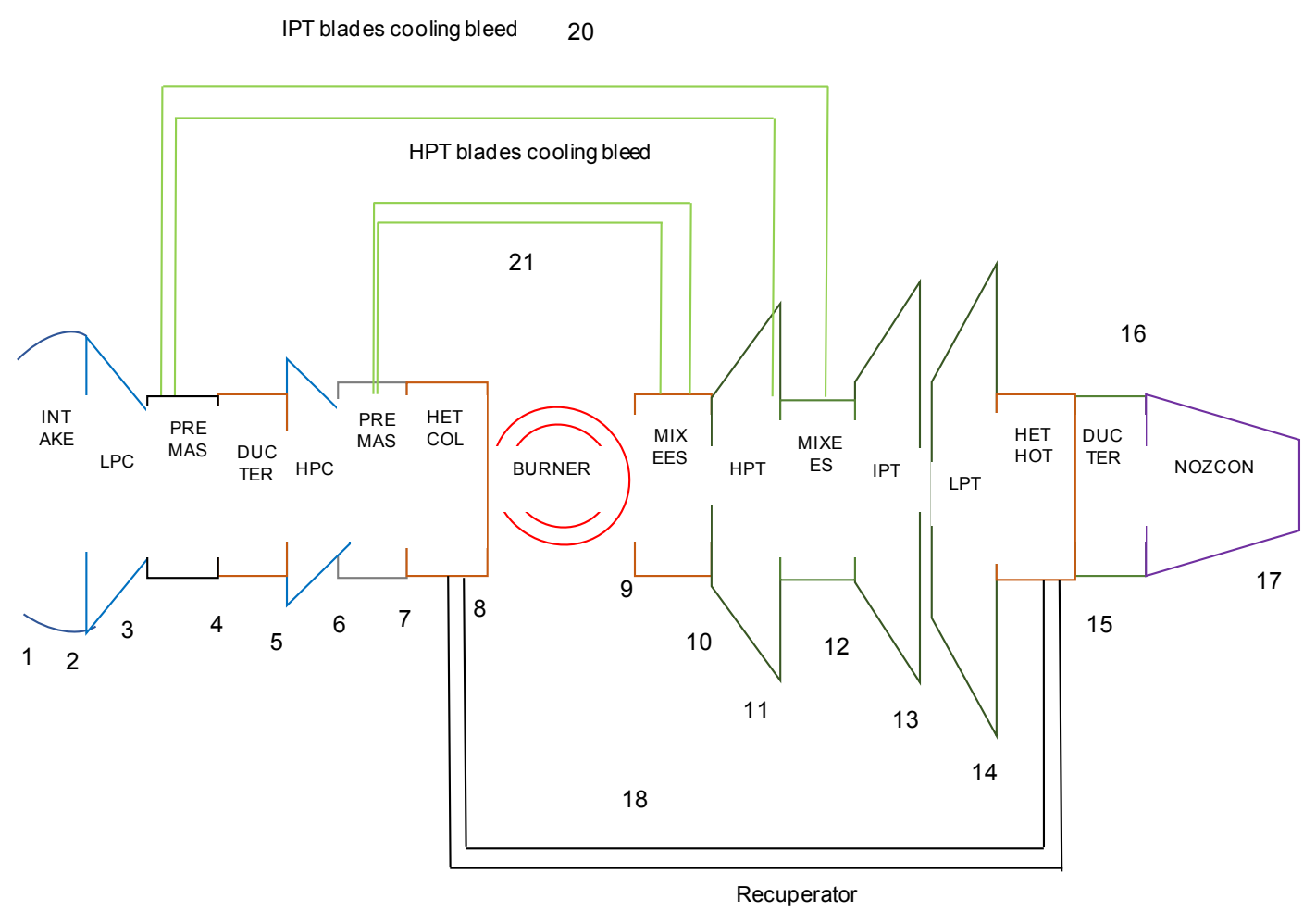

Figure 7. Intercooled/recuperated 3-spool LS2-ADIGT engine components in TURBOMATCH bricks (inspired by GE LMS100 core).

are retained except for the inclusion of a recuperator of $75 \%$ effectiveness, with cold side and hot side pressure losses of $1 \%$ and $2 \%$ respectively, of the inlet pressure, and $2 \%$ mass leakage. The inlet mass flow remains $215.5 \mathrm{~kg} / \mathrm{s}$ with a total of $27.4 \%$ bleed for both HPT and IPT inlet blades cooling. Also, keeping ISA SLS as design point, the engine was simulated and the summary of its DP performance shown in Table 1.

\subsection{Verification of Performance Results of Base Engine LS-ADIGT}

To verify the results of performance parameters of the simulated baseline engine, comparison is made with public domain source reference data of LMS100. This is shown in Table 2.

By the use of component maps in TURBOMATCH codes, the off-design performances of the SS-ADIGT engines were simulated and the variation of some key engine output parameters were plotted and presented in Figure 8 and Figure 9.

With reference to the simulation results shown in Table 1 and plots of Figure 8 and Figure 9, it could be observed that for the LS2-ADIGT the intercooled, and intercooled/recuperated, engines have increased thermal efficiency, compared to the simple cycle engine at both DP and off-design point. This is because the intercooler decreases the temperature of the air entering the HP compressor and as such reduces the HP compressor work. Similarly, recuperator increases the temperature of air entering the combustor to reduce the quantity of heat flow required from burning fuel by heat-exchange action with stream of exhaust gas. The ICR cycle combines both advantages of intercooling and heat-exchange discussed above to achieve increased thermal efficiency. In the same vein, heat rate is reduced in the advanced cycles compared to the simple cycle.

In Figure 10, the percentage increases at DP in thermal efficiency of the advanced cycle engines over the simple cycle engine are shown.

The negative sign on the heat rates in Figure 10 indicate percentage reduction in heat rate of advanced cycles over simple cycle. Of course increase in thermal efficiency is accompanied with corresponding decrease in heat rate for the ADIGT engines. The thermal efficiencies of intercooled engine cycle, and intercooled/recuperated engine cycles, over the simple cycle at design point increased by $2.42 \%$, and $0.94 \%$ respectively, whereas heat rates of these cycles over simple cycle at design point decreased by $2.37 \%$, and $0.93 \%$ respectively. 


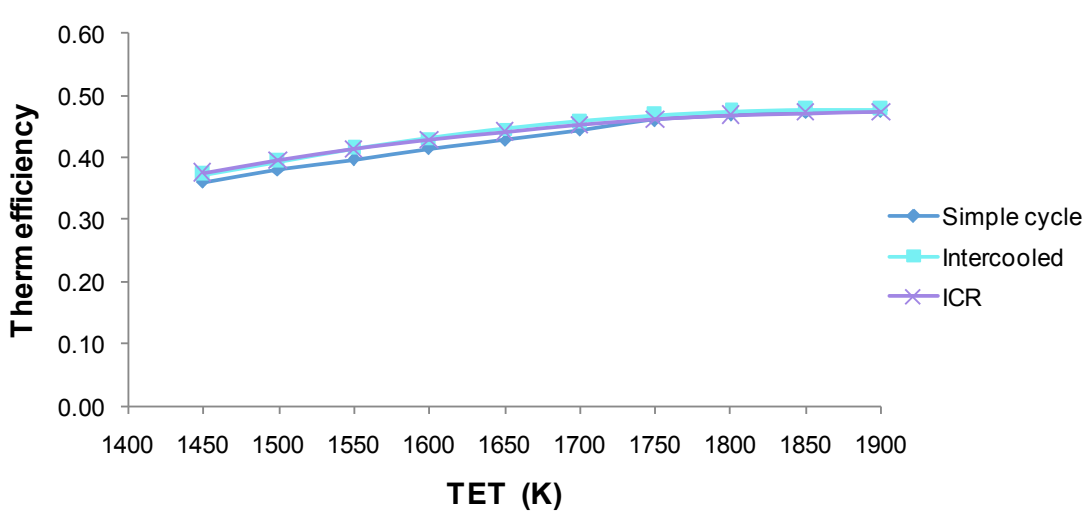

Figure 8. Variation of thermal efficiency with TET at ISA SLS (LS2-ADIGT).

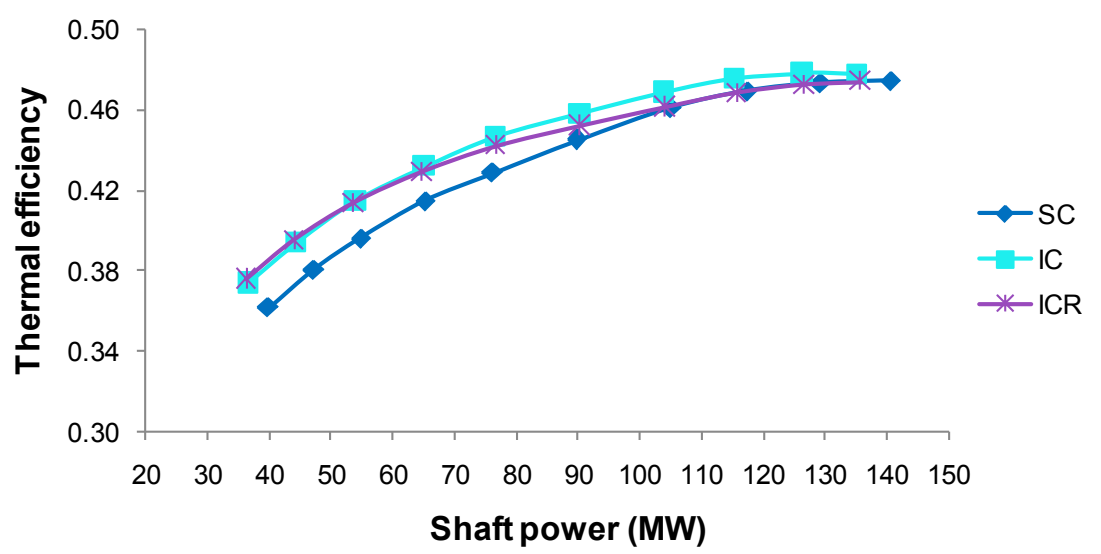

Figure 9. Thermal efficiency varying with shaft power at ISA SLS (LS2-ADIGT).

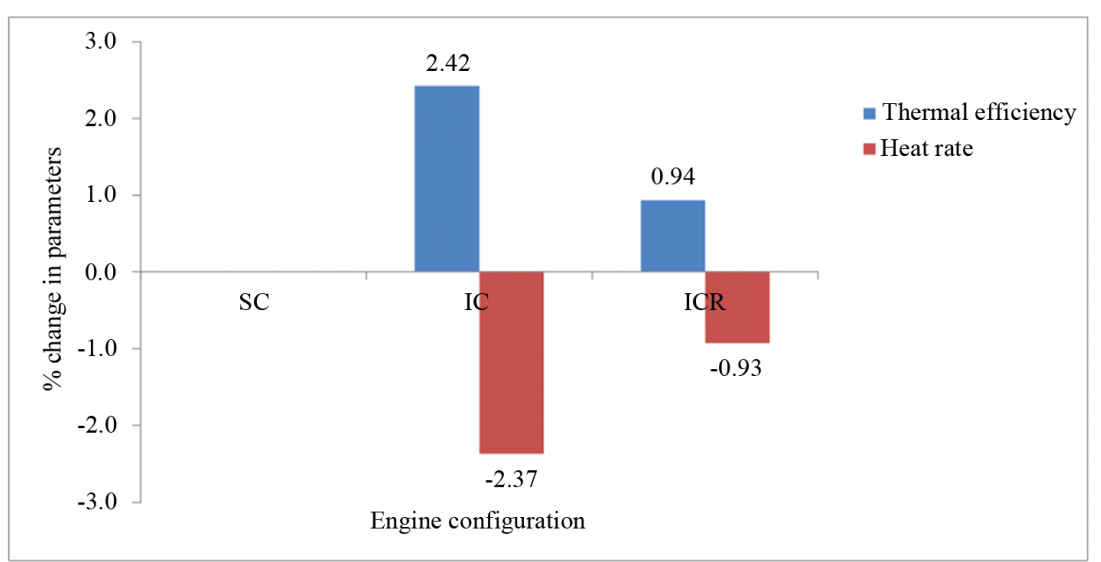

Figure 10. Percentage change in performance parameters of IC and ICR cycles over simple cycle for the LS2-ADIGT engines.

However, it is important to note that though the thermal efficiency is improved by using the advanced cycles, the incorporation of intercoolers and recuperators would make the engine more complex. This would increase the capital and maintenance cost actually, but cost of fuel would reduce due to reduction in heat rate and fuel consumption.

These results compare favorably with values obtained in the literature. For instance, it was reported that the 1.4 MW intercooled/recuperated Heron-1 turbo-shaft gas turbine manufactured by EECT of the Netherland exhibits thermal efficiency of $42.9 \%$ while a simple cycle gas turbine of same power range has thermal efficiency 
Table 2. Verifying performance results of simulated LS2-ADIGT engine.

\begin{tabular}{ccccc}
\hline \multirow{2}{*}{ Performance parameter } & \multicolumn{3}{c}{ Value at ISA SLS } \\
\cline { 2 - 5 } & Inspiring core LMS100 & Simulated baseline engine & Variation & $\%$ variation \\
\hline Power turbine rating & $100,000 \mathrm{~kW}$ & $100,000 \mathrm{~kW}$ & 0.00 & 0.00 \\
Inlet mass flow & $\mathrm{N} / \mathrm{A}$ & $215.5 \mathrm{~kg} / \mathrm{s}$ & - & -0.21 \\
Exhaust mass flow & $220 \mathrm{~kg} / \mathrm{s}$ & $220.47 \mathrm{~kg} / \mathrm{s}$ & -0.47 & - \\
Fuel flow & $\mathrm{N} / \mathrm{A}$ & $4.97 \mathrm{~kg} / \mathrm{s}$ & - & -0.87 \\
Exhaust gas temperature & $686 \mathrm{~K}$ & $692 \mathrm{~K}$ & -6 & -0.36 \\
Overall pressure ratio & $42.00: 1$ & $42.15: 1$ & -0.15 & -6.1 \\
Thermal efficiency & 0.440 & 0.467 & -0.027 & \\
\hline
\end{tabular}

of about $26 \%-34 \%$. This represents a thermal efficiency increase of about $26.2 \%$ at the minimum [27]. More so, percentage increases were reported of thermal efficiencies of recuperated engine cycle, and intercooled/recuperated engine cycle, over simple cycle of a turbo-shaft engine at DP as $20.6 \%$, and $24.2 \%$ respectively, whereas percentage reduction in specific fuel consumption of these cycles over simple cycle at DP as $17.3 \%$, and $21.1 \%$ respectively [15]. Similarly, It was found that thermal efficiencies of recuperated engine cycle, and intercooled/recuperated engine cycles, over the simple cycle at DP increased by $13.5 \%$, and $14.5 \%$ respectively, whereas percentage reduction in specific fuel consumption of these cycles over simple cycle at DP as $12.5 \%$, and $13 \%$ respectively [20].

\section{Conclusion}

Performance simulation of a simple cycle (baseline), IC and ICR three-spool large-scale aero-derivative industrial gas turbine derived from turbofan engine has been implemented. In doing so, design and off-design point performances of the engine models were established. It is found that the IC and ICR cycles exhibit better thermal efficiency than the simple engine. Similarly, heat rate in combustor is reduced in the advanced cycles than the simple engine. It is, however, worthy of note that for large-scale aero-derivative gas turbines having power rating of $100 \mathrm{MW}$ and above, intercooled cycle would consume less fuel than intercooled-recuperated and simple cycles. This finding would actually aid good choice of cycle option for large-scale aero-derivative gas turbine designers, manufacturers and users.

\section{Acknowledgements}

The authors would like to thank Prof. Pericles Pilidis and Dr. Theoklis Nikolaidis of the Department of Power and Propulsion of Cranfield University United Kingdom for their valuable contributions.

\section{References}

[1] Major, B. and Powers, B. (1999) Cost Analysis of NOx Control Alternatives for Stationary Gas Turbines. Onsite Sycom Energy Corporation. Report Prepared for US Department of Energy, Environmental Programs, Chicago, Accessed: 22 September 2013.

https://www1.eere.energy.gov/manufacturing/distributedenergy/pdfs/gas turbines_nox_cost_analysis.pdf

[2] Energy and Environmental Analysis (2008) Technology Characterization: Gas Turbines. A Report Prepared for Environmental Protection Agency Climate Protection Partnership Division, Washington DC, December 2008.

[3] Nkoi, B. (2014) Techno-Economic Studies of Environmentally Friendly Brayton Cycles in the Petrochemical Industry. $\mathrm{PhD}$ Thesis, Cranfield University, UK.

[4] Nkoi, B. and Lebele-Alawa, B.T. (2015) Comparative Assessment of Combined-Heat-and-Power Performance of Small-Scale Aero-Derivative Gas Turbine Cycles. Journal of Power and Energy Engineering, 3, 20-32. http://dx.doi.org/10.4236/jpee.2015.39002

[5] Bhargava, R.K., Blanchi, M., Campanari, S., Pascale, A., Montenegro, G.N. and Peretto, A. (2010) A Parametric Thermodynamic Evaluation of High Performance Gas Turbine Based Power Cycles. Journal of Engineering for Gas Turbines and Power, 132, Article ID: 022001. http://dx.doi.org/10.1115/1.3155782 
[6] Najjar, Y.S.H. (2000) Gas Turbines Cogeneration Systems: A Review of Some Novel Cycles. Applied Thermal Engineering, 20, 179-197. http://dx.doi.org/10.1016/S1359-4311(99)00019-8

[7] Yang, W. (1997) Reduction of Specific Fuel Consumption in Gas Turbine Power Plants. Energy Conversion and Management, 38, 1219-1224. http://dx.doi.org/10.1016/S0196-8904(96)00151-3

[8] Smith, R.P. (1996) Power Generation Using High Efficiency Gas Turbines, Opportunities and Advances in International Power Generation. IEE Conference Publication, Durham, 18-20 March 1996, 104-110.

[9] Mehmetli, B. and Wacek, E. (2010) High-Efficiency Combined Cycle Applications with New LM6000 Aero-Derivative Gas Turbines. The 16th International Energy and Environmental Fair and Conference, IGDAS, 12-14 May 2010 , 50-51.

[10] Keller, S.C. and Studniarz, J.J. (1987) Aero-Derivative Gas Turbines Can Meet Stringent NOx Control Requirements. Proceedings of the 9th Annual Industrial Energy Technology Conference, Houston, 16-18 September 1987, $253-260$.

[11] Roy, G.K. (2012) Selecting Heavy-Duty or Aero-Derivative Gas Turbines. Hydrocarbon Processing, $75,57$. http://web.ebscohost.com/ehost/delivery?sid=779a7995-8850-45b8-93ab-a0a1e7f07d

[12] Doom, T.R. (2013) Aero-Derivative Gas Turbines. Case Studies on the Government's Role in Energy Technology Innovation, American Energy Innovation Council, Accessed: 23 September 2013. http://americanenergyinnovation.org/wp-content/uploads/2013/08/Case-Gas-Turbines.pdf

[13] Dilba, D. (2012) Pioneering New Core Engine Technologies. MTU Aero Engines, MTU Aero Engines Holding AG.

[14] Paramour, M.D. and Sapsard, M.J. (1981) Future Technology and Requirements for Helicopter Engines. NATO AGARD Conference Proceedings of Helicopter Propulsion Systems, Toulouse, France, 11 - 14 May 1981, 1-6.

[15] Nkoi, B., Pilidis, P. and Nikolaidis, T. (2013) Performance Assessment of Simple and Modified Cycle Turboshaft Gas Turbines. Journal of Propulsion and Power Research, 2, 96-106. http://dx.doi.org/10.1016/j.jppr.2013.04.009

[16] Hartman, R.T.C. (1981) Gas Turbine Engineering: Application, Cycles, Characteristics. The MacMillan Press Ltd., London, 34-52.

[17] GE Power Generation. Aero-Derivative Gas Turbines. https://powergen.gepower.com/products/aeroderivative-gas-turbines.html

[18] Li, Y.G., Pilidis, P. and Newby, M.A. (2006) An Adaptation Approach for Gas Turbine Design-Point Performance Simulation. Journal of Engineering for Gas Turbines and Power of the ASME, 128, 789-795. http://dx.doi.org/10.1115/1.2136369

[19] Al-Hamdan, Q.Z. and Ebaid, M.S.Y. (2006) Modelling and Simulation of a Gas Turbine Engine for Power Generation, Journal of Engineering for Gas Turbines and Power of the ASME, 128, 302-311. http://dx.doi.org/10.1115/1.2061287

[20] Nkoi, B., Pilidis, P. and Nikolaidis, T. (2013) Performance of Small-Scale Aero-Derivative Industrial Gas Turbines Derived from Helicopter Engines. Journal of Propulsion and Power Research, 2, 243-253. http://dx.doi.org/10.1016/i.jppr.2013.11.001

[21] Palmer, J. (1999) The Turbomatch Scheme For Aero/Industrial Gas Turbine Engine Design Point/Off Design Performance Calculation. Cranfield University, Bedfordshire, Unpublished.

[22] MacMillan, W.L. (1974) Development of a Modular-Type Computer Program for the Calculation of Gas Turbine Off-Design Performance. PhD Dissertation, School of Engineering, Cranfield University, Bedfordshire.

[23] Galla, L., Volpe, V., Salussolia, M., Pachidis, V. and Jackson, A. (2012) Thermodynamic Gas Model Effect on Gas Turbine Performance Simulations. Journal of Propulsion and Power, 28, 719-727. http://dx.doi.org/10.2514/1.B34359

[24] Saravanamutoo, H.I.H., Rogers, G.F.C., Cohen, H. and Straznicky, P.V. (2009) Gas Turbine Theory. 6th Edition, Pearson Education Limited, New York, 1-3.

[25] Bromnick, P.A., Pearson, R.J. and Winterbone, D.E. (1998) Intercooler Model for Unsteady Flows in Engine Manifolds. Proceedings of the Institution of Mechanical Engineers, Part D: Journal of Automobile Engineering, 212, 119-132. http://pid.sagepub.com/content/212/2/119 http://dx.doi.org/10.1243/0954407981525849

[26] Ibrahim, T.K., Rahman, M.M. and Abdalla, A.N. (2010) Study on the Effective Parameter of Gas Turbine Model with Intercooled Compression Process. Scientific Research and Essays, 5, 3760-3770. http://www.academicjournals.org/SRE

[27] Farmer, R. (2002) Intercooled Recuperated 1400 KW Genset Has an 8000-Btu Heat Rate. Gas Turbine World, EECT B.V., The Netherland, March-April 2002. www.eect.nl 


\section{Nomenclature}

\begin{tabular}{|c|c|}
\hline $\mathrm{CW}$ & Compression work (unit: $\mathrm{kJ}$ ) \\
\hline $\mathrm{DP}$ & Design-point \\
\hline EW & Expansion work (unit: $\mathrm{kJ}$ ) \\
\hline FPT & Free power turbine \\
\hline FPTW & Free power turbine work \\
\hline GT & Gas turbine \\
\hline HP & High pressure \\
\hline HPC & High pressure compressor \\
\hline HPCW & High pressure compressor work \\
\hline HPT & High pressure turbine \\
\hline HPTW & High pressure turbine work \\
\hline IC & Intercooled cycle \\
\hline ICR & Intercooled/recuperated \\
\hline Inter & Intercooler \\
\hline ISA & International standard atmosphere \\
\hline ISA Dev & International standard atmosphere deviation \\
\hline LP & Low pressure \\
\hline LPC & Low pressure compressor \\
\hline LPCW & Low pressure compressor work \\
\hline LPT & Low pressure turbine \\
\hline OD & Off-design point \\
\hline OEM & Original equipment manufacturer \\
\hline OPR & Overall pressure ratio \\
\hline PR & Pressure ratio \\
\hline $\mathrm{SC}$ & Simple cycle \\
\hline SLS & Sea level static \\
\hline TET & Turbine entry temperature (unit: $\mathrm{K}$ ) \\
\hline TURBOMATCH & Gas turbine engine performance model code \\
\hline USAF & United State Air Force \\
\hline $\mathrm{c}$ & Specific heat (unit: $\mathrm{kJ} / \mathrm{kg}$ ) \\
\hline $\mathrm{c}_{\mathrm{p}}$ & Specific heat at constant pressure (unit: $\mathrm{kJ} / \mathrm{kg}$ ) \\
\hline $\mathrm{H}$ & Specific enthalpy (unit: $\mathrm{kJ} / \mathrm{kg}$ ) \\
\hline $\mathrm{P}$ & Total pressure (unit: $\mathrm{N} / \mathrm{m}^{2}$ ) \\
\hline Q & Heat flow (unit: kW) \\
\hline $\mathrm{q}_{\text {in }}$ & Heat flow in (unit: kW) \\
\hline $\mathrm{q}_{\text {out }}$ & Heat flow out (unit: kW) \\
\hline $\mathrm{S}$ & Entropy (unit: $\mathrm{kJ} / \mathrm{kgK}$ ) \\
\hline $\mathrm{SFC}$ & Specific fuel consumption (unit: kg/MWs) \\
\hline $\mathrm{T}$ & Total temperature (unit: K) \\
\hline \multicolumn{2}{|c|}{ Greek letters } \\
\hline$\eta$ & Efficiency (unit: \%) \\
\hline$\eta_{t h}$ & Thermal efficiency (unit: \%) \\
\hline$\eta_{c}$ & Compressor isentropic efficiency (unit: \%) \\
\hline$\eta_{T}$ & Turbine isentropic efficiency (unit: \%) \\
\hline \multicolumn{2}{|c|}{ Subscripts } \\
\hline $\mathrm{P}$ & At constant pressure \\
\hline Th & Thermal \\
\hline In & Inlet \\
\hline Out & Outlet \\
\hline Regen & Regeneration \\
\hline $1,2,3,4,5,6,7, \mathrm{i}$ & Engine components station numbers \\
\hline
\end{tabular}

